Kurnaz, H. ve Kasırga, D. (2021). Destekleme ve yetiştirme kurslarına yönelik Türkçe öğretmenlerinin görüşleri. Ana Dili Eğitimi Dergisi, 9(3), 708-725.

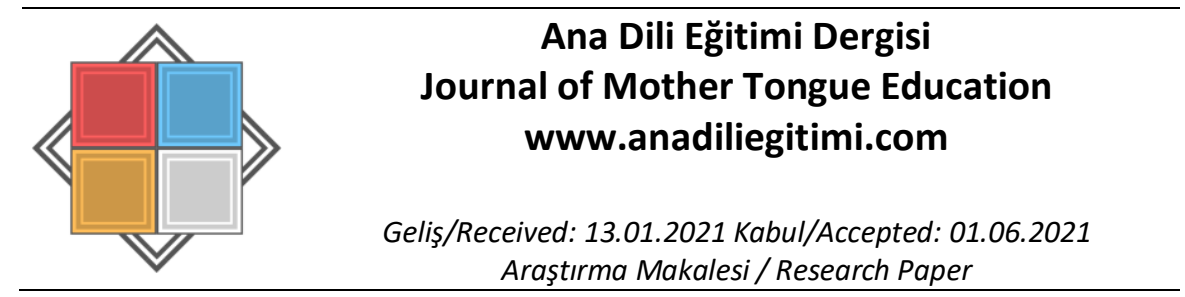

\title{
Destekleme ve Yetiştirme Kurslarına Yönelik Türkçe Öğretmenlerinin Görüşleri
}

\author{
Hasan KURNAZ* \\ Dilek KASIRGA ${ }^{* *}$
}

Öz

Bu çalışmanın amacı, destekleme ve yetiştirme kurslarındaki Türkçe derslerinin verimliliğini ve bu derslerde yaşanan sorunları, öğretmen görüşlerine göre belirlemektir. Çalışma, nitel araştırma desenlerinden fenomenoloji ile gerçekleştirilmiştir. Araştırmanın katıımcıları, amaçı örnekleme yöntemlerinden ölçüt örneklem ve maksimum çeşitlilik örneklem teknikleri kullanılarak belirlenmiştir. Çalışma grubu, farklı illerin ortaokullarında görev yapmakta olan 26 Türkçe öğretmeninden oluşmaktadır. Çalışmada, araştırmacılar tarafından geliştirilen yapılandırıımış görüşme formu kullanılmıştır. Araştırmada ayrıca, görüşme formundaki çevirim içi toplantı isteğini kabul eden 12 katılımcı ile video konferans yöntemiyle 40 dakikalık bir toplantı yapılmıştır. Araştırmanın verileri, içerik analizi yöntemiyle çözümlenmiş, derinlemesine yapılan incelemeyle katılımcı formları birden fazla kişi tarafından okunarak ortak kodlar belirlenmiştir. Araştırmanın geçerlik, güvenirlik ve etik ilkelere uygunluğunu sağlamak için çeşitli önlemler alınmıştır. Araştırmanın sonucunda elde edilen verilerin, destekleme ve yetiştirme kurslarının avantajlarının ve dezavantajlarının görülmesine ve bu kursların daha verimli olmasına katkı sağladığı söylenebilir. Anahtar Kelimeler: destekleme ve yetiştirme kursu, Türkçe öğretmeni, görüşme

\begin{abstract}
Turkish Language Teachers' Views on Supporting and Training Courses Abstract

The aim of this study is to examine the efficiency of Turkish lessons in supporting and training courses and determine the problems experienced in these lessons according to teachers' opinions. The study was carried out by using the phenomenology method, which is one of the qualitative methods. The participants were determined by using criterion sampling and maximum diversity sampling techniques, which were among purposive sampling methods. The relevant study group consisted of 26 Turkish teachers working in the secondary schools of different provinces. A structured interview form developed by the researchers was used in the collection of data. Moreover, in the study, a 40-minute meeting was held on Zoom with 12 participants, who accepted the online meeting request on the interview form. The data of the research were analysed by the content analysis method. In the in-depth examination, more than one person read the participant forms, and common codes were determined. Various measures were taken to ensure the validity and reliability of the study, and its compliance with ethical principles. It can be concluded that the data obtained as a result of the study contributed to determining the advantages and disadvantages of the supporting and training courses and to make these courses more efficient.

Keywords: supporting and training courses, Turkish language teachers, interview
\end{abstract}

\footnotetext{
* Dr. Öğr. Üyesi, Gaziantep Üniversitesi, Nizip Eğitim Fakültesi, Türkçe ve Sosyal Bilimler Eğitimi Bölümü, Gaziantep, kurnazhasan44@gmail.com, ORCID: https://orcid.org/0000-0002-5804-946X

** Öğretmen, Millî Eğitim Bakanlığı, Kahramanmaraş, dilekdilek1907@gmail.com, ORCID:

https://orcid.org/0000-0003-2965-3657
} 


\section{Giriş}

Eğitim sistemi içerisinde, daha seçkin bir üst kademeye geçmek için yapılan merkezî sınavlar, öğrencileri özel öğretim kurumlarına yönlendirmektedir. Öğrenciler seçkin liselere ve üniversitelere yerleşebilmek için merkezî sınavlarda, iyi puanlar almak zorundadır. Okullarda verilen eğitim, merkezî sınavlarda, iyi puan almak için pek çok öğrenci ve veli tarafından yetersiz görülmektedir. Öğrenciler; test tekniği kazanma, zaman kullanımı, sınav stratejileri vb. pek çok beceriyi edinmek için özel öğretim kurumlarına yönelmektedir. Ülkemizde özel öğretim kurumlarına duyulan talep, genellikle merkezî sınavların varlı̆̆ı ile açıklanmaktadır (Kösterilioğlu, 2015). Ancak bu durum sadece ülkemize mahsus değildir. Eğitim kademeleri arasındaki geçişlerde rekabete dayalı sınav sistemlerinin olduğu pek çok ülkede, özel ders ve dershanecilik oldukça yaygındır (Tansel ve Bircan'dan akt. Özoğlu, 2011).

Ülkemizde ortaöğretime geçişte uygulanan sınavların tarihi, çok eskilere dayanmaktadır. 1955 yılında kurulan Maarif Kolejlerinin sınavla öğrenci alma uygulaması, pek çok seçkin lise tarafından benimsenerek yaygınlaşmıştır (Güven, 2010). Seçkin liselere yerleşecek öğrencilerin belirlenmesi, 1955-1997 yılları arasında, okullara özgü dar katılımlı seçme sınavları ile yapılmış; ancak bu uygulama, talebin artmasıyla yetersiz kaldığı için 1997'de, LGS (Liselere Giriş Sınavı) isimli merkezî bir sınava geçilmiştir (Atılgan, 2018). Seçkin liselere yerleşecek öğrencileri belirlemek için yapılan sınavın adı ve uygulanış şekli zaman zaman değişse de merkezî sınav, günümüze değin varlığını devam ettirmektedir. Merkezî sınava dayalı, rekabetçi bir eğitim sistemi içerisinde, devlet okullarında verilen eğitimin yetersiz görülmesi; çocukları için büyük bir beklenti içerisine giren velileri, farklı eğitim arayışlarına yönlendirmektedir. Bu da dershanelerin ortaya çıkmasına sebep olmuştur. Literatürde, öğrencilerin dershane başarılarının merkezî sınav başarılarını etkilediği bulgusuna (Kanat, 2005; Morgil, Yılmaz ve Geban, 2001) rastlanmaktadır.

Tamamlayıcı eğitim olarak adlandırılan ek ders, kurs, özel ders, birebir ders gibi uygulamalara, dünyada pek çok ülkede rastlanmaktadır (Sarıca, 2019). Eğitimde uluslararası eğilim, gölge eğitim olarak adlandırılan tamamlayıcı eğitime yöneliktir (Tan, 2017). Birçok ülkede öğrenciler, okul derslerine ilave olarak tamamlayıcı eğitim niteliğindeki özel ders ve dershane hizmeti almaktadır. Tamamlayıcı eğitim faaliyetleri, ülkelerin eğitim sistemi içerisinde, farklı şekillerde yer alabilmektedir. Bunlar, bir öğretmenin bire bir öğrenciye özel ders vermesi, okullara benzer biçimde örgütlenen özel dershaneler ve okul öğretmenlerinin okul içinde ders saatlerinin dışında belirli bir ücret karşılığında ders vermeleridir (Tansel, 2013: 11). Singapur, Hong Kong, Güney Kore ve Tayvan gibi ülkelerde bir öğretmen tarafından verilen özel ders uygulaması daha yaygınken (Bray ve Lykins, 2012), ülkemizde özel dershane uygulaması yaygındır. Tamamlayıcı eğitim hizmetleriyle ilgili en çok dile getirilen sorun, fırsat eşitliğidir. Yukarıda belirtilen bir ve ikinci gruptaki uygulamalar, yüksek ücretler gerektirdiği için düşük gelirli öğrencilerin bunlardan faydalanamadığı belirtilmektedir (TED, 2010). Ücretli özel öğretim kurumlarının, fırsat eşitliği başta olmak üzere pek çok soruna neden olduğu vurgulanmaktadır (Göksu ve Gülcü, 2016). Bu sorunların önde gelenleri arasında; eğitim hizmetlerinin ticarileştirilmesi, ekonomik durumu iyi olmayan ailelerin maddi olarak zor durumda bırakılması, okullarda yürütülen eğitimöğretim faaliyetlerinin olumsuz etkilenmesi, ezberci eğitime yönlenme (Bozbayındır ve Kara, 2017) gösterilebilir. Millî Eğitim Bakanlığı eğitimde fırsat eşitliğini sağlamak için yukarıda bahsedilen, üçüncü gruptaki tamamlayıcı eğitim hizmetini, 2014-2015 eğitim-öğretim yılında devreye sokmuştur. Bu eğitim-öğretim yılı itibariyle tüm ortaokul ve liselerde destekleyici eğitim kapsamında kurslar verilmeye başlanmıştır (MEB, 2014). Ücretsiz olarak verilen bu kurslarla eğitimde fırsat eşitliğinin arttırılması hedeflenmiştir.

Eğitimde fırsat eşitliği, başka bir ifade ile eğitim ve öğretimi ilgilendiren her şeyin adil bir şekilde düzenlenmesi gereği, her çağda önemini koruyan bir meseledir. Eğitimde fırsat eşitliği, eğitimle ilgili tüm kaynaklara ayrımcılık yapılmadan bütün kişilerin sahip olabilmesi ve herkesin kendini, yeteneklerini geliştirebilmesi adına, eğitimle ilgili tüm hizmetlerden faydalanabilmesi olarak açıklanmaktadır (Tezcan, 1997). Eğitim hakkı, bireyin en temel hakkıdır. Türkiye Cumhuriyeti Anayasası'nın 42. maddesiyle bu hak güvence altına alınmıştır (TBMM, 2020). Coğrafi bölgeler arasındaki farklııklar, ekonomik ve kültürel koşullar, günümüzde halen eğitimde fırsat eşitliğinin önünde engel olarak durmaktadır. Ekonomik koşulları daha iyi olan ailelerden gelen öğrenciler, eğitimle ilgili daha iyi olanaklara sahiptir. Olanakların artması; birey, okul ve bölge başarısına yansımaktadır. 
Türkiye'nin PISA (MEB, 2019a) verileri, öğrenci başarısının; coğrafi bölgeler, okul türleri ve ailelerin sahip olduğu maddi varlıklara göre önemli düzeyde değiştiğini göstermektedir.

Destekleme ve yetiştirme kursları (DYK), MEB'e bağlı ortaokul ve liselerde okuyan öğrencilere yönelik olarak örgün eğitim kurumlarında hizmet vermektedir. Kurslar, okul derslerine ilave olarak hafta içinde veya hafta sonunda okul içerisinde yapılmaktadır (MEB, 2016). Bakanlığın verilerine göre kursların ilk açıldığı 2014-2015 eğitim-öğretim senesinde yaklaşık 2 milyon 600 bin öğrenci, bu kurslara devam etmiştir. Bu sayı, 2016- 2017 eğitim-öğretim yılında, 4 milyon 450 bine ulaşmıştır (MEB, 20172018). Bu verilerden hareketle, kurslara olan talebin her geçen gün katlanarak arttığı söylenebilir.

Destekleme ve yetiştirme kurslarında verilecek dersler, MEB'in düzenlediği yönerge ve ekılavuzlarla belirlenmektedir. Bunun yanı sıra, MEB Ölçme, Değerlendirme ve Sınav Hizmetleri Genel Müdürlüğü (ÖDSGM) Destekleme ve Yetiştirme Kursları sayfasında; kazanım kavrama testleri, beceri testleri, tekrar testleri, soru arşivleri ve DYK derslerine yönelik yıllık plan örnekleri bulunmaktadır. Türkçe dersi ile ilgili bu sayfalarda yer alan materyaller incelendiğinde, kurslarda öğrencileri LGS'ye hazırlayacak konu ve kazanımlara ağırlık verildiği söylenebilir.

Eğitimde fırsat eşitliği yaratmayı hedefleyen DYK'larda, kurs başarısı MEB tarafından yakından izlenmektedir. Kursların kalitesini değerlendirmek için kursta açılan derslerden her ay, kazanım kavrama ve değerlendirme sınavlarının yapılacağı ilgili yönergelerde belirtilmektedir. Ayrıca tüm derslerden her dönem sonunda, ÖDSGM tarafından, izleme ve değerlendirme amaçlı ortak bir sınavın yapılacağı ifade edilmektedir (MEB, 2020). Çoktan seçmeli sorulara dayanan bu sınavların, en önemli amacının öğrencileri LGS'ye hazırlamak olduğu düşünülebilir. DYK yönergesinde bunlara ek olarak denetleme formuna da yer verilmiştir. Bu formda belirtilen ölçütlerin, öğretmen ve yöneticilerin sorumluluklarını gösterdiği ve denetleyicilerin neyi, nasıl değerlendireceklerini betimlediği düşünülebilir. Sonuç olarak MEB'in bu kurslara büyük önem verdiği, bu kursların, dershanelerin yerini alması için gerekli yasal düzenlemeleri yaptığı ve kursların verimliliğini yakından takip ettiği söylenebilir.

Destekleme ve yetiştirme kurslarının verimliliği ve aksayan yönlerini belirlemeyi amaçlayan, pek çok akademik çalışmaya rastlanmaktadır. Bu çalışmalar, tarafsız ve eleştirel bir bakış açısı sunduğu için son derece önemlidir. Bu konuda yapılan çalışmalarda, destekleme ve yetiştirme kurslarının verimi; öğrenci (Akkaya, 2017; Aküzüm ve Saraçoğlu, 2018; Er Türküresin, 2018, Keskin ve Kazak, 2020), öğretmen (Bozbayındır ve Kara, 2017; Er Türküresin, 2018; Nartgün ve Dilekçi, 2016; Topcu ve Ersoy, 2019) ve yönetici (Canlı, 2019; Dönmez, Gürbüz ve Tekçe, 2018; Yirci ve Açıkgöz, 2018) görüşlerine göre incelenmiştir. İlgili çalışmalarda; kurslarda öğrencilerin sıklıkla devamsızlık yaptığı (Topcu ve Ersoy, 2019), öğrencilerin kursları yorucu bulduğu ve kendilerini sosyal olarak kısıtlanmış hissettikleri (Er Türküresin, 2018; Yirci ve Açıkgöz, 2018), öğretmenlerin kurslarda kaynak sıkıntısı yaşadığı (Yirci ve Açıkgöz, 2018) ve fiziki yetersizliklerin bulunduğu (Dönmez, Gürbüz ve Tekçe, 2018) belirtilmektedir. Destekleme ve yetiştirme kurslarının olumsuz olduğu kadar olumlu yönleri de bu çalışmalarda ortaya konmuştur (Keskin ve Kazak, 2020). Öğretmenlerin bu kurslara yönelik üst düzeyde olumlu tutuma sahip olduğu (Aküzüm ve Saraçoğlu, 2018), öğrencilerin büyük çoğunluğunun kurslarla ilgili olumlu düşünceler belirttiği (Nartgün ve Dilekçi, 2016) ve kursların fırsat eşitliği yarattığına inanıldığı (Er Türküresin, 2018) belirlenmiştir. Ayrıca kursların, öğrencilerin okul derslerine destek olduğu (Bozbayındır ve Kara, 2017), onların test çözme becerilerini geliştirdiği (Akkaya, 2017) ve sınav başarılarını arttırdığı (Yirci ve Açıkgöz, 2018) tespit edilmiştir.

DYK ile ilgili yapılan çalışmalarda, salt Türkçe dersi ve Türkçe öğretmenlerine yönelik herhangi bir çalışmanın olmaması, bu çalışmanın dayanak noktasıdır. Altı yılık bir uygulama olan destekleme ve yetiştirme kursları hakkında, Türkçe branşı bazında yeterli bir araştırma yapılmamış olması, bu araştırmanın önemini artıran unsurlardandır. Bu çalışmada, destekleme ve yetiştirme kurslarındaki Türkçe derslerinin verimliliği ve bu derslerde yaşanan sorunların öğretmen görüşlerine göre belirlenmesi hedeflenmektedir. Araştırmada aşağıdaki sorulara yanıt aranmıştır:

1. Destekleme ve yetiştirme kurslarını Türkçe öğretmenleri nasıl değerlendirmektedir? MEB bu uygulamaya devam etmeli midir?

2. Destekleme ve yetiştirme kurslarında Türkçe öğretmenlerinin Türkçe dersi açısından karşılaştığı sorunlar nelerdir?

3. Kursların daha etkili ve verimli olması için neler yapılabilir? 


\section{Araştırmanın Modeli}

\section{Yöntem}

Bu çalışma, nitel araştırma desenlerinden biri olan fenomenoloji (olgubilim) ile gerçekleştirilmiştir. Fenomenolojik bir çalışma, insanların bazı olguları, nasıl tecrübe ettiklerinin metodolojik, özenli ve derinlemesine bir şekilde betimlenmesini gerektirir (Patton, 2014). Bu tür çalışmalarda olgu, yaşadığımız dünyada karşımıza çıkabilen olay ve deneyimleri ifade etmektedir (Yıldırım ve şimşek, 2013). Fenomenoloji deseninde, bireylerin bir kavram ya da olguya ilişkin deneyimlerini ortaya çıkarmaya yönelik çalışmalar yapılmaktadır (Creswell, 2013). Bu çalışmanın odağındaki olgu, Türkçe öğretmenlerinin destekleme ve yetiştirme kurslarıyla ilgili deneyim ve düşünceleridir. Bu kurslarda çalışan Türkçe öğretmenlerinin DYK ile ilgili genel görüşlerini belirlemek için fenomenoloji deseni benimsenmiştir. Özetle kurslarda verilen Türkçe eğitiminin niteliği, öğrencileri ve sistemi en iyi tanıyan kişiler olan öğretmenlerin bakış açısıyla ele alınmıştır.

\section{Katılımcılar}

Bu araştırmanın katılımcıları, amaçlı örnekleme yöntemlerinden ölçüt örneklem ve maksimum çeşitlilik örneklem teknikleri kullanılarak belirlenmiştir. Çalışmanın katılımcılarını belirlemede kullanılan ölçüt; daha önce destekleme ve yetiştirme kurslarında en az bir yıl Türkçe öğretmeni olarak çalışmak ve araştırmaya gönüllü olarak katılmak olarak tanımlanmıştır. Araştırmada maksimum örnekleme yöntemi, çalışma grubunun farklı kıdeme ve değişik çalışma şartlarına sahip kişilerden oluşmasını sağlamak için seçilmiştir. Öğretmenlerin DYK ile ilgili deneyim ve düşünceleri, kıdem ve cinsiyet değişkeninden etkilenebildiği için çalışma grubunun bu değişkenler açısından çeşitlenmesi hedeflenmiştir. Bu çeşitliliğin araştırmada incelenen olguya yönelik deneyim ve düşünceleri daha iyi anlamaya katkı sağlayacağı düşünülmektedir. Araştırmanın çalışma grubunu, farklı illerin ortaokullarında görev yapmakta olan 26 Türkçe öğretmeni oluşturmaktadır. Katılımcılara ilişkin rumuz isimler, çalışılan şehir, cinsiyet ve kıdem bilgileri Tablo 1'de verilmiştir.

Tablo 1.

Katılımcılara ilişkin Bilgiler

\begin{tabular}{lllcc}
\hline Öğretmenler & Çalıştığı şehir & Cinsiyet & Kıdem & DYK Yılı \\
\hline Açelya & Şanlıurfa & Kadın & 5 & 2 \\
Ahsen & Şanlıurfa & Kadın & 5 & 2 \\
Abdullah & Kahramanmaraş & Erkek & 11 & 4 \\
Ahmet & Kahramanmaraş & Erkek & 16 & 6 \\
Ali & Kahramanmaraş & Erkek & 7 & 6 \\
Anıl & Kahramanmaraş & Erkek & 11 & 3 \\
Aysun & Kahramanmaraş & Kadın & 10 & 4 \\
Başak & Gaziantep & Kadın & 6 & 5 \\
Burcu & Gaziantep & Kadın & 2 & 2 \\
Cansu & Gaziantep & Kadın & 6 & 6 \\
Ceyda & Gaziantep & Kadın & 3 & 3 \\
Dilek & Kilis & Kadın & 8 & 4 \\
Ece & Kilis & Kadın & 7 & 3 \\
Eda & Kilis & Kadın & 6 & 3 \\
Elif & Gaziantep & Kadın & 5 & 3 \\
Fatih & Hatay & Erkek & 9 & 4 \\
Fatma & Gaziantep & Kadın & 10 & 4 \\
Fatoş & Kahramanmaraş & Kadın & 7 & 5 \\
Gülay & Şanlıurfa & Kadın & 19 & 3 \\
Hacer & Şanlıurfa & Kadın & 5 & 5 \\
İlayda & Gaziantep & Kadın & 8 & 4 \\
Ilyas & Kahramanmaraş & Erkek & 15 & 4 \\
Jale & Şanlıurfa & Kadın & 3 & 2 \\
\hline
\end{tabular}




\begin{tabular}{lllll}
\hline Kaan & Hatay & Erkek & 5 & 2 \\
Kadir & Şanlıurfa & Kadın & 7 & 2 \\
Kuzey & Şanlıurfa & Erkek & 6 & 5 \\
\hline
\end{tabular}

Katılımcı öğretmenlerin 17'si kadın, 9'u erkektir. Mesleki çalışma yılı 5 ve altı olan 8 kişi, 6-10 yıl arası olan 13 kişi, 11 yıl ve üstü olan ise 5 kişi bulunmaktadır. Öğretmenlerin 3'ü DYK'ların başladığı ilk yıldan beri bu kurslarda çalışmakta, 6 'sı ise 2 yıldır kurslarda çalışmaktadır.

\section{Verilerin Toplanması}

Ortaokul düzeyinde görev yapan Türkçe öğretmenlerinin destekleme ve yetiştirme kurslarına ilişkin görüşlerinin belirlendiği bu araştırmada, araştırmacılar tarafından geliştirilen yapılandırılmış görüşme formu kullanılmıştır. Görüşme formu, katılımcılara çevirim içi form olarak gönderilmiş ve bu şekilde veriler toplanmıştır. Toplam 11 sorudan meydana gelen görüşme formunda, katılımcı öğretmenlerin demografik bilgilerini öğrenmek için 4 soru, kurslarla ilgili görüşlerini betimlemek için ise açık uçlu 7 soruya yer verilmiştir.

Başlangıçta, araştırmanın amacı ve ilgili araştırmalar göz önünde bulundurularak öğretmenlerin DYK'larla ilgili deneyim ve düşüncelerini sorgulayan, açık uçlu sorulardan oluşan taslak bir form hazırlanmıştır. Araştırmacılar tarafından hazırlanan formun kapsam geçerliliğini sağlamak amacıyla, uzman görüşüne başvurulmuştur. Eğitim programları ve öğretimi alanında doktora derecesine sahip üç uzman; taslak formu, anlaşılma ve araştırılan konuyu kapsama düzeyi bakımından incelemiş̧ir. Uzmanların önerileri doğrultusunda düzenleme yapılmıştır. Soruların anlaşıırlığını test etmek için iki Türkçe öğretmeni ile yüz yüze görüşme yapılarak görüşme formuna son şekli verilmiştir.

Araştırma verileri, 20-30 Mayıs 2020 tarihleri arasında toplanmıştır. Çevrimiçi form olarak hazırlanan görüşme formu, ikinci araştırmacının sosyal medya hesabı (Facebook) kullanılarak paylaşılmıştır. Görüşme formu, Türkçe öğretmenlerinin sosyal medyada oluşturduğu ve üye sayıları binden fazla olan beş farklı grupta paylaşılmıştır. Katılımcılara; araştırmanın amacı, gizlilik protokolü ve katılım şartlarını açıklayan bir yönerge sunularak kendileriyle paylaşılan elektronik formu gönüllü bir şekilde doldurup doldurmayacakları sorulmuştur. Katılmak isteyen öğretmenler, bağlantıya tıklayarak görüşme formundaki soruları yanıtlamıştır. Görüşme formundaki çevirim içi toplantı isteğini kabul eden 12 katılımcı ile de video konferans yöntemiyle 40 dakikalık bir toplantı yapılmıştır. Araştırmaya katılmayı kabul eden kişilerin doldurduğu elektronik formlar ve video konferans kayıtları, bir klasörde depolanmıştır.

\section{Verilerin Analizi}

Araştırmanın verileri, içerik analizi yöntemiyle çözümlenmiştir. Araştırmada öncelikle elektronik ortamda 37 katılımcıdan elde edilen formlar, ön incelemeye alınmıştır. Bu inceleme sırasında, bazı katılımcıların (11 katıımcı) doldurduğu formlarda; gerekçeli açıklamaların olmaması, sade ve yüzeysel cevapların yer alması gibi nedenlerden dolayı belirtilen formların uygun olmadığına karar verilmiş ve bunlar çalışmaya dâhil edilmemiştir. Derinlemesine yapılan incelemede, geriye kalan 26 katılımcının formları ve video konferansın kayıtları, birden fazla kez incelenerek ortak kodlar belirlenmeye çalışılmıştır. Elde edilen kodlardan, üst kategoriler oluşturularak temalar belirlenmiştir. Son olarak elde edilen nitel verilerin, frekans değerleri alınarak tablolara aktarılmıştır. Her katılımcı birden fazla cevap verebildiğinden, kodların hesaplanan frekans değeri, cevapların sıklık değerini göstermektedir. Katılımcıların cevaplarından ve ilgili kodlardan elde edilen ana temalar bulgular bölümünde sunulmuştur.

\section{Geçerlik ve Güvenirlik}

Araştırmanın geçerlik ve güvenirlik ilkelerine uygunluğunu sağlamak için bazı önlemler alınmıştır. Araştırmanın iç geçerliliğini sağlamak için veri ve analizci çeşitlemesine yer verilmiştir. Veri çeşitlemesi için çevirim içi toplantıyı kabul eden katılımcılarla odak grup görüşmesi yapılmış ve derinlemesine sorular sorulmuştur. Analizci çeşitlemesi için, bütün formlar ve video kayıtları iki araştırmacı tarafından ayrı ayrı kodlanmış, ardından her bir araştırmacının oluşturduğu kodlar, diğer 
araştırmacı tarafından kontrol edilmiştir. Farklı tespit edilen kodlar üzerinde tartışmalar yapılarak karar verilmiştir. Çalışmada, uzman incelemesi tekniğine de başvurulmuştur. Bu teknik, elde edilen ham bulgu ve yorumların birbiriyle örtüşmesi için yapılan meslektaş görüşmesini ifade etmektedir (Merriam, 2013). Araştırmacılar, deşifre ettiği görüşme formları ve video kayıtlarından elde ettiği kod ve temaları, nitel araştırmalar alanında uzman bir kişinin onayına sunmuştur. Uzmanla yapılan teyit toplantısında araştırmacıların belirlediği kod ve temalar ile ilgili dönütler alınmıştır.

Araştırma sonuçlarının benzer gruplar ya da ortamlara aktarılabilirliği (Yıldırım \& Şimşek, 2013) için katılımcıların ifadeleri doğrudan alıntı yapılarak sunulmuş ve katılımcıların çeşitli özellikleri belirtilmiştir. Doğrudan alıntıların seçilmesinde; ilgili tema ve kodu en iyi şekilde destekleyecek bir kanıt ve yeterli bir örnek olma, kriter olarak belirlenmiştir. Veri toplanan her bir öğretmene, rumuz bir ad verilmiş (Açelya, Ahsen vb.) ve böylelikle katılımcıların gizli tutulması sağlanmıştır. Araştırmanın geçerliğini ve güvenirliğini arttırmak için analizlerden elde edilen bulgular, yorum yapılmadan sunulmuştur.

\section{Araştırma ve Yayın Etiği}

Bu çalışmada "Yükseköğretim Kurumları Bilimsel Araştırma ve Yayın Etiği Yönergesi" kapsamında uyulması belirtilen tüm kurallara uyulmuştur. Yönergenin ikinci bölümü olan "Bilimsel Araştırma ve Yayın Etiğine Aykırı Eylemler" başlığı altında belirtilen eylemlerden hiçbiri gerçekleştirilmemiştir.

\section{Etik Kurul izni}

Kurul adı = T.C. Gaziantep Üniversitesi, Sosyal ve Beşeri Bilimler Etik Kurulu Komisyonu

Karar tarihi $=9$ Eylül 2020

Belge sayı numarası $=91611957 / 100 / 57047$

\section{Araştırmanın Birinci Alt Problemine ilişkin Bulgular}

\section{Bulgular}

Türkçe öğretmenlerinin destekleme ve yetiştirme kurslarını nasıl değerlendirdikleriyle ilgili görüşlerinden elde edilen tema ve kodlar Tablo 2'de sunulmuştur.

Tablo 2.

Türkçe Öğretmenlerine Göre Destekleme Ve Yetiştirme Kursları

\begin{tabular}{llc}
\hline Tema & Kod & Frekans \\
\hline & Fırsat eşitliği & 17 \\
Fırsat Eşitliği & Tekrar fırsatı & 14 \\
$(\mathrm{f}=42)$ & Test çözme imkânı & 14 \\
& Sınavlara hazırlık imkânı & 3 \\
& Akademik gelişime katkı & 2 \\
\hline \multirow{2}{*}{ Öğrenci İ̧in Dezavantajlar } & Yorgunluk & 17 \\
$(\mathrm{f}=23)$ & Devamsızlık & 4 \\
& İlgisizlik & 2 \\
\hline \multirow{2}{*}{ Öğretmen İçin Dezavantajlar } & Yorgunluk & 3 \\
$(\mathrm{f}=6)$ & Kolay maddi kazanç & 2 \\
& Yetersiz ders saati & 1 \\
\hline
\end{tabular}

Tablo 2 incelendiğinde, Türkçe öğretmenlerinin destekleme ve yetiştirme kurslarına ilişkin görüşlerinin sırasıyla; fırsat eşitliği $(f=42)$, öğrenci için dezavantajlar $(f=23)$ ve öğretmen için dezavantajlar $(f=6)$ temaları altında toplandığı görülmektedir. Öğretmenler, eğitimin önündeki maddi engelleri ortadan kaldırdığı ve eğitimde fırsat eşitliğini sağladığı için DYK'ların devam etmesi gerektiğini, savunmuştur. Kaan öğretmen, eğitim imkânlarının paralı olmaya doğru gittiği günümüzde, DYK'ların kaliteli eğitime ulaşmaktaki fırsat eşitsizliğini ortadan kaldırdığını belirtmiştir. Benzer şekilde Burcu ve 
Kuzey öğretmen de sınavlara hazırlık için her türlü imkâna sahip olan öğrencilerle maddi durumu yetersiz olan öğrencilerin yarışabilmesi için DYK'ların önemini şu şekilde belirtmiştir:

Destekleme ve yetiştirme kurslarını, eğitimde eşitlikçi bir yaklaşım olarak görüyorum. Ekonomik durumu iyi olmayıp farklı kaynaklardan (özel ders, özel etüt gibi) yararlanmayan öğrenciler için bir fırsat eşitliği sunuyor. Ögrenciler bu kurslar sayesinde test çözebiliyor, sınavlara hazırlanabiliyor. Bu kursların kaldırıması ekonomik durumu iyi olmayan öğrencilerin başarı fırsatını yok eder. Burcu

Bu kurslar MEB'in "firsat eșitliği" ilkesini ete kemiğe büründürmektedir. Bu kurslar kaldırılırsa özel ders alabilen, dershanelere gidebilen ögrenciler ile bunlardan yararlanamayan öğrenciler arasındaki makas açılacaktır. Ayrıca kırsal kesimde yaşayan çocukların okumaya dair hayallerine darbe vurulmuş olacağını düşünüyorum. Kursları kaldırmak yerine bu çocuklar için kursları, daha nitelikli hale getirmeliyiz. Kuzey

Birçok öğretmen kursların, maddi imkânları yetersiz olan çocuklar için önemli avantajlar sağladığını dile getirmiştir. Test çözme $(f=14)$, tekrar yapma $(f=14)$, sınavlara hazırlanma $(f=3)$, akademik gelişim $(\mathrm{f}=2)$ bu avantajlardan bazılarıdır. Öğretmenler, hafta içi okulda müfredatı yetiştirme kaygısı duydukları için test çözme ve tekrar yapmaya zamanlarının olmadığını, bu yönüyle DYK'ların avantaj sağladığını belirtmiştir. Bu kurslar sayesinde öğrencilerin, konuyla ilgili daha fazla soru görme ve öğretmenle birlikte, bire bir soru çözme imkânı kazandığı görüşü sıkça vurgulanmıştır. Bu konuyla ilgili Cansu ve Ali öğretmenin görüşleri şu şekildedir:

MEB DYK uygulamasına devam etmeli. Çünkü Bu kurslar, öğrencinin hafta içinde gördüğü dersleri pekiştirme görevi üstlenmektedir. Bu kurslar, konular hakkında daha çok uygulama, soru çözümü ve alıştırma imkânı sağlıyor. Öğrencilerin dersi tekrar etmesine, konu ile ilgili daha çok test çözebilmesine olanak sağlıyor. Dersteki eksikliklerini kapamasına yardımcı oluyor. Cansu

Bu kurslar, kesinlikle devam etmeli; çünkü okuldaki derslerde genel konu anlatımı yapılmakta ve yeterli alıstırma yapmaya zaman kalmamaktadır. Okulda konuları tam öğrenemeyen veya eksik öğrenen öğrenciler için kurslar çok faydalı. Öğrenciler konunun değişik yönlerini daha detaylı öğrendikleri için onları akademik olarak geliş̧tirmektedir. Alıştırma yapmaya ihtiyaç duyan öğrencilere, test çözme imkânı sağladığı için öğrenciler sınavlara daha iyi hazırlanmakta. Ali

Kursların fırsat eşitliği ve çeşitli avantajlar sağlamasıyla birlikte öğretmenler tarafından olumsuz bulunan bazı özellikleri de bulunmaktadır. Öğrenci için dezavantajlar teması altındaki görüşlerde; öğrencilerin yoğun ders temposundan çok fazla yorulduğuna ( $f=17)$ dikkat çekilmektedir. Hafta içi okul ve sonrasında kurs olmasının öğrencilere ağır geldiği bu yüzden öğrencilerin derslerde devamsızlık yaptığı $(f=4)$ ve kursa karşı isteksiz olduğu $(f=2)$ vurgulanmaktadır. Kursların öğrenciler için dezavantajı yönlerinin, DYK'lardan verim alınmasını engellediğini, Abdullah öğretmen şu şekilde belirtmiştir:

Kursların verimli olduğunu düşünmüyorum. Öğrenciler hiç dinlenme fırsatı bulamıyorlar. Hafta içi ders saatinin (yedi saat) fazla olması öğrencinin algı düzeyinin düşmesine neden oluyor, üstüne bir de kurs derslerinin eklenmesi... Eğitimdeki bu olanağın (DYK'nın) verimsiz hale geldiğini düşünmekteyim. Yetişkin bir birey bile haftada dokuz saat ders başında bulunamaz. Bu uygulamanın ücretsiz olması, birçok öğrencinin katılabilmesi adına güzel fakat yoğun ders saatlerinin olması uygulamayı olumsuz yapıyor.

Kursların öğretmenler için dezavantajlı yönlerini belirten görüşlerde de kursların verimsiz olduğuna dikkat çekilmektedir. Kursların öğretmenler için de yorucu olması $(f=3)$, öğretmenlerin kursları sadece maddi kazanç yeri olarak görmesi ve kurslara yeterince önem vermemesi $(f=2)$ verimsizliğin nedeni olarak gösterilmektedir. İlyas öğretmen kurslardan verim alınamadığını ve kurs uygulamasına MEB'in son vermesi gerektiğini şu şekilde belirtmiştir:

Bence MEB kurslara devam etmemeli. Çünkü eğitim amacının dışına çıktı. Kurslar öğrenciler için çalışıyor görünme, öğretmenler için kolay para kazanma yolu oldu. Kursun amacı destekleme olması gerekirken, öğrencinin önüne test koyup zaman geçirme etkinliğine dönüşü. Kurs öğrenciye test çözdürmekten başka bir işe yaramıyor.

\section{ikinci Alt Probleme ilişkin Bulgular}

Türkçe öğretmenlerinin kurslarda karşılaştığı sorunlarla ilgili görüşlerinden elde edilen tema ve kodlar Tablo 3' te sunulmuştur. 
Tablo 3.

Kurslarda Türkçe Öğretmenlerinin Karşılaştığı Sorunlar

\begin{tabular}{llc}
\hline Tema & Kod & Frekans \\
\hline & Öğrencilerin ilgisizlı̆̈i & 13 \\
& Devamsılık & 8 \\
Motivasyon Problemi & Öğrencilerin yorgunluğu & 7 \\
$(\mathrm{f}=39)$ & Hazırbulunuşluk düzeyi & 6 \\
& Ailede motivasyon eksikliği & 3 \\
& Yetersiz çalışma & 2 \\
\hline \multirow{3}{*}{ Müfredat Problemi } & Kurs test çözme ağılıklı & 7 \\
$(\mathrm{f}=15)$ & Kurs dil bilgisi ağırlıklı & 4 \\
& Konu sıralaması farklı & 2 \\
\hline \multirow{2}{*}{ Materyal Problemi } & Ders saati yetersiz & 2 \\
$(\mathrm{f}=12)$ & Kaynak yetersizliği & 10 \\
& Öğretmen farklıı̆ı & 2 \\
\hline
\end{tabular}

Tablo 3 incelendiğinde, Türkçe öğretmenlerinin destekleme ve yetiştirme kurslarında karşılaştı̆̆ı sorunlara ilişkin görüşlerinin sırasıyla; motivasyon problemi ( $f=39$ ), müfredat problemi $(f=15)$ ve materyal problemi $(f=12)$ temaları altında toplandığı görülmektedir. Öğretmenler en çok öğrencilerin motivasyon düşüklüğünden şikayetçidir. Motivasyon düşüklüğünün nedeni olarak birçok öğretmen ilgisizlik $(f=13)$ ve yorgunluğu $(f=7)$ göstermektedir. Kursların öğrencileri yorduğu, öğrencilerde derslere ve kursa karşı bir bıkkınlık, isteksizlik oluşturduğu belirtilmektedir. Anıl ve Açelya öğretmenin bu konudaki görüşleri şu şekildedir:

Öğrencide kursa karşı yeterince ilgi olmuyor, veli yeterince bilinçli değil. Hafta içi okulun normal eğitim süresinin üzerine yapılan kurs, öğrenciye ağır geliyor. Günlük yedi saat ders, üstüne kurs verimsiz kalıyor. Hafta sonu olunca da dinlenme ve eğlenme süresinden kısıldığı kanaati oluşuyor. Öğrenciler DYK olduğu günlerde okula geliyormuş gibi hissediyor ve zihin olarak tam anlamıly kendini dışarıdan koparamıyor. Ayrıca aynı konular, müfredat dâhilinde ders sırasında işlenince ilgi daha yüksek olabiliyor ama DYK sırasında ikinci defa işlenince ilgi azalıyor ve öğrencide biz zaten biliyoruz, düşüncesi oluşuyor. Anıl

Derse ilgisi ve isteği olmayan öğrencilere fazla faydalı olamıyoruz Türkçe dersini sevmeyen öğrenci kursta da başarısız oluyor. Derse ilgili olarak gelen öğrencilerde başarı artıyor. Ama isteksiz ve aile baskısı ile gelen çocuklarda derse ilgi de olmadığından bu tarz öğrencilerde artış olmuyor Kurs ücretsiz olduğu için ilgisiz öğrenciler de katılıyor. Bu sebeple onlara katkı sağlayamıyoruz. Açelya

Motivasyon problemi temasında en çok tekrar eden bir diğer sorun da devamsızlıktır. Birçok öğretmen $(f=8)$, devamsızlı̆ın kurstan kayıt silmek dışında herhangi bir yaptırımı olmadığı için öğrencilerinin derslere düzenli katılmadığını söylemektedir. Gülay öğretmenin bu konudaki görüşleri şu şekildedir:

Öğrencilerin bir süre sonra devamsızlık yapmaları en büyük sorun. Gelmemesinin kurstan kaydı silinmesi dışında bir yaptırımı olmamasııı bilen öğrenci, bu konuda kendini zorlamıyor. Bu biraz da okulumun bulunduğu köy ortamından kaynaklanıyor. Kursların 10 öğrencinin altına düşmesi sonucu hemen kapanması bizi zorluyor. Devamsızlık yapan veya düzenli gelmeyen öğrencilerle sürekli iletişim kurarak veya velilerle iş birliği yaparak çözmeye çalışıorum.

Motivasyon problemi temasında dile getirilen sorunlardan biri de öğrencilerin performansı ile ilgilidir. Öğrencilerin; hazırbuluşluk düzeyinin düşük olması ( $f=6)$ ve yetersiz çalışmalarının $(f=2)$ başarı ve motivasyonu olumsuz etkilediği belirtilmektedir. Öğrencilerin hazırbulunuşluk düzeyinin yetersiz olmasının genellikle bilgi/okuma eksikliği, çalışma alışkanlığının olmayışı ve ailelerin ilgisizliği ile açıklandığı görülmektedir. Hacer öğretmenin bu konudaki görüşleri şu şekildedir:

Genelde başarısı pek fazla iyi olmayan öğrencilerimizde, kursta biraz olumlu yönde bir artış olsa da ne yazık ki süreklilik sağlanamıyor. Normal eğitim yaşamında da geçerli olan sebepler kursta da başarııı olumsuz etkiliyor. Temeli zayıf olan öğrenciler kurslarda genelde başarısız oluyor. Öğrencinin en 
temelden gelen bilgi eksikliği var, dersi almaya karşı güdü eksikliği var, ders çalışma alışkanlığı sorunu var.

Müfredat temasında, kursun test çözme $(f=7)$ ve dil bilgisi $(f=4)$ ağırlıklı olmasının pek çok öğretmen tarafından sorun olarak algılandığı görülmektedir. Hafta içi okulda yapılan Türkçe derslerinde, anlama ve anlatma becerilerinin tamamına yönelik etkinlikler yapılırken kurslarda daha çok okuduğunu anlama ve dil bilgisi konuları ile ilgili test çözmeye ve pratik yapmaya ağırlık verilmektedir. Bu tarz bir ders, bazı öğrenciler için çok eğlenceli olsa da bazıları için takip etmesi güç, yoğun ve sıkıcı olmaktadır. Bu konu ile ilgili illayda öğretmenin görüşleri şu şekildedir:

Kursta dört temel beceriye pek fazla yer verilmiyor, okuldaki Türkçe dersinde konu, dört temel beceri üzerine işleniyor. Kursta edebi yön daha az. Şiir, hikâye vs. çok az. Kurs daha çok dil bilgisi, yazım kuralları vb. test çözme ağırlıklı. Bu sınava gerçek manada hazırlanan öğrenciler için çok faydalı, ama sınav başarısı düşük olan öğrenciler için hiç de eğlenceli değil.

Müfredat teması altında, ifade edilen diğer bir sorun da kurstaki konu sıralamasının okuldaki konu sıralamasında farklılığıdır $(f=2)$. Okuldaki Türkçe dersinin yıllık planı ile kurstaki Türkçe dersinin planı uyumlu olmadığı için konuların işleniş sıraları farklılık göstermektedir. Bu farklılık, öğrencilerin aynı konuyu tekrarlı bir şekilde dinlemesine neden olabilmektedir. Kadir öğretmenin bu konudaki görüşleri şu şekildedir:

Genellikle okul ve kurs konuları uyumlu. Fakat bazı konu sıralamaları değişiklik gösterebiliyor. Örneğin bu sene kurstaki plana göre zarf konusunu vermem gerekirken okulda henüz o konuya geçmemiştik. Öğrenciler konuyu ilk defa kursta dinleyecekse soru çözmeye zaman az kalıyor. Aynı konuyu kursta ikinci kez dinleyeceklerse de sıkılabilmekteler. Aynı konuyu farklı çalışma kâğıtları, akılı tahtalar ile uyumlu farklı programlar ve internet üzerinden farklı sitelerdeki etkinlikleri yaparak bu durumda tekrara düşmemeye çalışıyoruz.

Müfredat teması altında belirtilen bir diğer sorun, kurslardaki Türkçe ders saatinin yetersizliğidir $(\mathrm{f}=2)$. Türkçe dersine okulda haftalık 5 saat ayrılırken, kursta verilen haftalık 2 ders saatinin; konuları kavratmak ve test çözmek için yeterli olmadığı vurgulanmaktadır. Ahmet öğretmenin bu konudaki görüşleri şu şekildedir: "Kendi derslerimde karşılaştığım en büyük sorun zaman sorunu. Türkçe derslerinde konu anlatımı, bazı konularda uzayabiliyor. Sizse elinizdeki planı yetiştirmeye çalışıyorsunuz bu durum zorlayıcı olabiliyor. Her ne kadar planlamalar, kazanımlara göre yapılsa da süre sıkıntısı çekiliyor."

Destekleme ve yetiştirme kurslarında, Türkçe öğretmenlerinin karşılaştığı sorunların yoğunlaştığı bir diğer tema, materyal problemi $(f=12)$ temasıdır. Bu tema altında öğretmenlerin kursta kullanmak için hem kendilerinin kaynak sıkıntısı çektiği hem de öğrencilerin evde çalışmaları için yeterli kaynağa sahip olmadıklarını belirttiği görülmüştür. Birçok öğretmen; maddi durumu iyi olan öğrencilerin bir şekilde kendine test kitabı alabildiğini; ancak maddi durumu iyi olmayan öğrencilerin bu konuda, sıkıntı yaşadığını belirtmektedir. Jale öğretmenin bu konudaki görüşleri şu şekildedir:

Kaynak konusunda derslerde sıkıntı yaşamaktayım. Konu anlatımından hemen sonra öğrencilerle yeterli soru çözülmelidir. Ancak öğrenciler yeterli kaynağa sahip değil. EBA'daki testler yetersiz kalıyor. Öğrencilere ücretsiz verilebilecek kaynaklar olsa ders çok daha verimli ve düzenli işlenebilir. Akıllı tahtada kullanılabilecek etkileşimli etkinlik ve testler arttırılsa dersler daha çok verimli olur.

Materyal teması altında belirtilen diğer sorunlar; sınıfların kalabalıklığı $(f=1)$ ve öğretmenlerin tanımadıkları öğrencilerin dersine görevlendirilmeleridir $(f=2)$. Aysun öğretmen bu sorunu şöyle belirtmektedir: "Bazen hafta içi dersine girmediğiniz dolayısıyla hakkında fikir sahibi olmadığınız öğrencilerle dersiniz olabiliyor. Öğrencinin hafta içi derslerde olan performansını bilmemek yanıltıcı olabiliyor; çünkü öğrencinin başarı seviyesi hakkında fikir sahibi değilseniz bir de süre sıkıntısı yaşıyorsanız, istediğiniz başarı seviyesine ulaşamayabiliyorsunuz."

\section{Üçüncü Alt Probleme ilişkin Bulgular}

Destekleme ve yetiştirme kurslarının daha verimli olması için neler yapılması gerektiğiyle ilgili Türkçe öğretmenlerinin belirttiği görüşlerden elde edilen tema ve kodlar Tablo 4' te sunulmuştur. 
Tablo 4.

Kursların Daha Verimli Olması İçin Öğretmenlerin Çözüm Önerileri

\begin{tabular}{llc}
\hline Tema & Kod & Frekans \\
\hline & Kurs günü/saati & 9 \\
& Türkçe ders saati & 4 \\
& Müfredat daha az ve esnek olmalı & 4 \\
Yönetim Boyutu & Denetim ve yönetim faaliyetleri & 3 \\
$(\mathrm{f}=30)$ & Devamsızlık sorunu & 3 \\
& Öğretmen ve ders seçimi & 3 \\
& Kursiyer seçimi & 2 \\
& Aile ile işbirliği & 2 \\
\hline \multirow{3}{*}{ Öğretmen Boyutu } & Sosyal etkinliklere yer verilmeli & 7 \\
(f=15) & Temel dil becerilerine ağılık verilmeli & 5 \\
& Konuların işlenme düzeni & 2 \\
\hline \multirow{2}{*}{ Materyal Boyutu } & Türkçe dersi basit algısı yıkılmalı & 1 \\
$(\mathrm{f}=13)$ & MEB kaynak dağıtmalı & 7 \\
& Akıllı tahta aktif kullanılmalı & 4 \\
\hline
\end{tabular}

Tablo 4 incelendiğinde, destekleme ve yetiştirme kurslarının daha verimli olması için Türkçe öğretmenlerinin belirttiği görüşlerin sırasıyla; yönetim boyutu $(f=30)$, öğretmen boyutu $(f=15)$ ve materyal boyutu $(f=13)$ temaları altında toplandığı görülmektedir. Öğretmenler en çok kurs günü/saati $(f=9)$ ile ilgili öneride bulunmuştur. Destekleme ve yetiştirme kurslarına gösterilen ilginin düşük olması, kurslarda motivasyonun ve başarının düşük olması gibi pek çok durum kurs günü/saatinin uygunsuzluğu ile açıklanmaktadır. Kursun hafta içi mi hafta sonu mu olması gerektiği ile ilgili bildirilen görüşlerin, zaman zaman birbiriyle çeliştiği de söylenebilir. Bazı öğretmenlere göre kurslar, okul çıkışı yorucu olacağı için hafta sonunun sadece bir gününde yapılmalı, bazılarına göre ise kurslar çocukların eğlenme zamanı olarak gördükleri hafta sonlarında yapılmamalı, okul çıkışında yapılmalıdır.

Yönetim boyutu temasında yoğunlukla dile getirilen diğer kodlar; Türkçe ders saatinin artırılması $(f=4)$ ve müfredatın esnetilmesidir $(f=4)$. Türkçe ders saatinin arttırımasının; öğrencilerin okuma ve anlama ile ilgili problemlerini çözeceği, bunun diğer derslere de olumlu yansıyacağı belirtilmektedir. Öğretmenlere göre müfredatın hafifletilmesi ve esnetilmesi, öğretmenlerin yetkisini arttıracak ve bölgesel şartların daha çok dikkate alınmasını sağlayacaktır. Ahmet öğretmenin bu konudaki görüşleri şu şekildedir:

Kesinlikle 2 ders saati yetersiz. Ders saatleri güncellenmeli. Ders saati en az bir saat daha arttırılabilir. Türkçe ders sayılarının artırımasııın yanında, dersin planlanması aşamasında da öğretmene esneklik şansı verilmeli. Çerçeve plan hazırlanırken ülkenin farklı bölgeleri ve değişik sosyoekonomik durumlar göz önünde bulundurulmalı.

Birçok öğretmene göre, derslere düzenli katılım olmadığında aksaklıklar yaşanmakta ve öğrencilerin kurstan aldığı verim düşmektedir. Devamsızık sorunu $(f=3)$ başta olmak üzere karşılaşılan pek çok sorunun çözümü için denetim ve yönetim faaliyetlerinin arttırılması $(f=3)$ gerektiği vurgulanmaktadır. Devamın sağlanması için öğrencilere teşvik amaçlı ödüller verilmesi ve dikkat çekici sosyal etkinliklerin yapılması önerilmektedir. Ceyda öğretmenin bu konudaki görüşleri şu şekildedir:

Kursların daha düzenli ve sistemli olması gerektiğini düşünüyorum. Idare kurslara okul dersi gibi önem vermeli, devamlıı̆̆ı sağlamalıdır. Devamsızlık yapan öğrencilerle sürekli iletişim kurulmalı ve bunların kursa devam etmesi sağlanmalı. Sosyal etkinlik ve eğlenirken öğrenme amaçı, dönemde birkaç kez il veya ilşe bazında çeşitli etkinlikler (film/tiyatro gösterimi, bilgi yarışması, öğretici oyunlar) planlanabilir. Böylelikle öğrencinin hem destekleme ve yetiştirme kurslarına ilgisi çekilir, hem stres atması sağlanır.

Önemli sayıda öğretmene göre kursiyer seçimi, ders ve öğretmen seçimi ile ilgili problemler, kursların verimini olumsuz etkilemektedir. Öğretmenlerin kurs için kendi okullarının dışında görevlendirilmelerinin ve başarısı düşük olan öğrencilerin kursiyer olarak seçilmesinin kurs başarısını düşürdüğü ifade edilmektedir. Fatoş öğretmenin bu konudaki görüşleri şu şekildedir: 
Öğrenciler hangi dersin kursunu almak istiyorsa onu almalı, mümkünse o derse giren öğretmenden almalı. Bir okulda derse giren branş öğretmenin farklı bir okulun DYK'sında görev almasının faydalı olmayacağını düşünüyorum. Aileler gönüllü katılım için bilinçlendirilmeli. Eğer bu kursun amacı lise sınavı için öğrenci hazırlamak ise, ortalama standardı getirilerek gerçekten hazırlanan öğrenciler kursa seçilmeli.

Türkçe öğretmenlerinin önemli bir kısmı kursların daha verimli ve etkili olması için öğretmen boyutunu ilgilendiren önerilerde bulunmuştur. Öğretmenler, öğrencilerin kurslara ilgisinin çekilmesi ve devamın sağlanması için derslerde daha fazla sosyal etkinliğe $(f=7)$ ve temel dil becerilerine daha çok ağırlık $(f=5)$ verilmesi gerektiğini belirtmiştir. Derslerin test merkezli işlenmesinin başarısı düşük öğrencilerin dikkatini çekmediği, bunu kırmak için sosyal etkinliklere yer vererek öğrencilerin ilgisini çekmenin önemine dikkat çekilmiştir. Bunun bir yolunun da kurslarda sadece okuduğunu anlama ve dil bilgisi konularının işlenmesi yerine güzel konuşma, sanatsal etkinlikler, keyifli dinletiler vb. faaliyetler olduğu vurgulanmıştır. Elif öğretmenin bu konudaki görüşleri şu şekildedir:

Türkçe dersi için ise temel dil becerilerine öncelik verilip öncelikle öğrencilerin bu alanda gelişmeleri sağlanmalıdır Ders süreci; konuşma, okuma, yazma, dil bilgisi gibi gruplandırılarak anlatılmalı. Ders kelime oyunları ve eğlenceli içeriklerle de desteklenmeli. Sadece konu anlatmak yerine etkinlik saatleri konulabilir. Kitap okuma saati eklenebilir. Bunun için DYK müfredatı biraz hafifletilmeli. Müfredattaki konuları azaltılıp eğlenceli etkinliklere daha fazla yer açılabilir.

Türkçe öğretmenlerinin büyük bir kısmı kursların daha verimli ve etkili olması için materyal boyutunu ilgilendiren önerilerde bulunmuştur. Öğretmen görüşlerine göre kurslarda yaşanan en büyük problemlerden birisi de kaynak yetersizliğidir. MEB'in tüm okullara belli bir kaynak dağıtmasının bu sorunu çözeceği ve fırsat eşitliği sağlayacağı görüşü $(f=7)$ sıkça vurgulanmaktadır. Fatma öğretmenin bu konudaki görüşleri şu şekildedir:

Öğretmenlerin öğrencilere dağıtacağı test, kitap vb. kaynakların temini MEB tarafından ücretsiz olursa hem öğretmenlerin fotokopi çekme sıkıntıları azalır hem de imkânı olmayan öğrenciler için fırsat eşitliği olur. MEB kurslara daha fazla basılı kaynak göndermeli. Öğretmen ve öğrenciler en azından kazanım testlerinin basılı haline ulaşıp kullanabilmeli.

Materyal boyutu temasında, öğretmenlerin kaynak probleminin çözümüyle ilgili belirttiği bir diğer önerisi de akıllı tahtada kullanılabilecek etkinlik ve aktivitelerin arttırılması ( $f=4)$ ve EBA'nın geliştirilmesi $(f=2)$ olmuştur. Teknolojinin bu kadar geliştiği bir dönemde eğitimde teknolojik materyallerin kullanılmasının kaçınılmaz olduğu vurgulanmaktadır. İlyas öğretmenin bu konudaki görüşleri şu şekildedir:

Akıllı tahta kullanımı artırılmalı, ülke geneline yayılmalı ve kullanımın çoğunlukla öğrenciye bırakılması gerektiğini düşünüyorum. Öğrencinin kendinin düşünüp bulması, cevabı bulması öğrenmesi için çok önemli olduğu kanaatindeyim. Akıllı tahtanın daha da aktif kullanılması için akıllı tahta uyumlu akıllı defterler, kaynaklar alınabilir. EBA'da bulunan etkileşimli etkinlikler çok güzel fakat az. Bunlar çoğaltılmalı.

\section{Tartışma ve Sonuç}

Bu çalışmada, destekleme ve yetiştirme kurslarındaki Türkçe derslerinin verimliliği ve bu derslerde yaşanan sorunların öğretmen görüşlerine göre belirlenmesi hedeflenmiştir. Araştırmada elde edilen bulgulara göre Türkçe öğretmenlerinin büyük çoğunluğu, destekleme ve yetiştirme kursu uygulamasını, doğru bulmakta ve MEB'in bu uygulamaya devam etmesi gerektiğini düşünmektedir. Öğretmenler bu düşüncelerine, özellikle kursların eğitimde fırsat eşitliğini sağlamasını gerekçe olarak göstermektedir. Çoğu öğretmene göre kurslar, ekonomik durumu iyi olmayan öğrencilerin sınava hazırlık sürecinde, test tekniklerini geliştirmelerine ve daha başarılı olmalarına katkı sağlamaktadır. Destekleme ve yetiştirme kurslarının en önemli amacı, eğitimin önünde duran ekonomik engelleri ortadan kaldırmaktır. Türkçe öğretmenlerinin çoğunluğu, kursların bu hedefi yerine getirdiğini ve MEB'in DYK'lara devam etmesinin faydalı olacağını düşünmektedir. Literatürde yer alan diğer çalışmalarda (Aküzüm ve Saraçoğlu, 2018; Canlı, 2019; Er Türküresin, 2018; Uğurlu, 2017) da benzer sonuçlara rastlanmaktadır. Uğurlu (2017), Aküzüm ve Saraçoğlu (2018) yaptıkları çalışmalarda, öğretmenlerin DYK'lara yönelik tutumlarının üst düzeyde olumlu olduğunu tespit etmiştir. Er Türküresin (2018) yaptığı çalışmada, destekleme ve yetiştirme kurslarının en önemli işlevinin 
öğrenciler arasında fırsat eşitliği sağlama olduğunu belirlemiştir. Canlı (2019) çalışmasında; kursların maddi açıdan yetersiz olan ve etüt merkezine gidemeyen veya özel ders alamayan öğrencilere, ekstra ders alabilme imkânıyla fırsat eşitliği sağladığını ortaya koymuştur. Bu çalışmada pek çok öğretmen, kursların öğrencilerin akademik gelişimlerine katkı sağladığı, onların konu tekrarı yapmalarına ve sınavlara hazırlanmalarına olanak tanıdığını ifade etmiştir. Benzer şekilde Ünsal ve Korkmaz (2016), Nartgün ve Dilekçi (2016) de yaptıkları çalışmalarda, örgün eğitim-öğretim sürecinde istedikleri düzeyde soru çözme fırsatı bulamayan öğrencilerin, kurslar sayesinde bu fırsatı elde ettiklerini belirlemiştir. Canlı (2019) çalışmasında, DYK'ların öğrencilere konu eksikliklerini tamamlama, konuları tekrar etme, farklı örnekler çözme, farklı etkinlikler yapma, çok sayıda soru çözme gibi imkânlar sağladığını bulmuştur. Ülkemizin eğitim sistemi, sınav odaklı olduğu için pek çok aile, öğrenci ve öğretmene göre başarının göstergesi merkezî sınavlardan alınan yüksek puanlardır. Merkezî sınavlarda yüksek puanlar almak için öğrencilerin iyi bir sınava hazırlık sürecinden geçmesi ve çokça test çözmesi gerekmektedir. Destekleme ve yetiştirme kursları, özellikle maddi durumu yetersiz olan öğrencilere bu imkânı sağlamıştır. Bu yönüyle kursların fırsat eşitliğini sağlayan önemli bir mekanizma olduğu söylenebilir.

Kursların, fırsat eşitliği ve çeşitli avantajlar sağlamasıyla birlikte öğretmenler tarafından olumsuz bulunan bazı özellikleri de bulunmaktadır. Öğretmenler kendileri ve öğrencileri açısından kursların bazı dezavantajlarının olduğunu ve bunların da kurstan beklenen verimi düşürdüğünü belirtmektedir. Özellikle kurs günü ve saatinin uygun olmamasının öğrencilerde motivasyon düşüklüğüne, yorgunluğa ve devamsızlığa neden olduğu ifade edilmektedir. Hafta içi okul dersleri hafta sonu da kurs dersleri öğrencilere ağır gelmekte, öğrenciler dinlenmeye ve eğlenmeye vakit bulamamaktadır. Bu alanda yapılan diğer çalışmalarda da, kursların yoğun olduğu ve bu durumun yorgunluğa sebebiyet verdiği vurgulanmaktadır (Bozbayındır ve Kara, 2017; Canlı, 2019; Nartgün ve Dilekçi, 2016). Merkezî sınavlara hazırlanmak, bütün uğraşısı dershaneye gitmek ve test çözmek olan bir öğrenci tipi ortaya çıkarmaktadır (TED, 2006). Öğrencilerin çok küçük yaşlardan itibaren bu kurumlara devam etmek zorunda kalmaları, onların sosyal ve ruhsal gelişimlerini olumsuz etkilemektedir (Kösterilioğlu, 2015). İlköğretim çağındaki öğrencilerin, uzun ve yorucu sınava hazırlık maratonu boyunca, bu tip bir öğrenciliği sürdürmede zorlanması son derece normaldir.

Araştırmanın ikinci alt problemiyle ilgili görüşlere bakıldığında Türkçe öğretmenlerinin kurslarda karşılaştığı en büyük sorunun motivasyon problemi olduğu görülmektedir. Öğrencilerin kursa karşı ilgisiz olmaları ve sıkça devamsızık yapmaları en sık rastlanan sorunlardandır. Öğrenciler derslere düzenli katııım sağlamadığı için konular arasında kopukluk yaşandığı, bunun da öğrenci başarısını düşürdüğüne inanılmaktadır. Bu konuda yapılan diğer çalışmalarda da (Bozbayındır ve Kara, 2017; Canpolat ve Köçer, 2017; Er Türküresin, 2018; Göksu ve Gülcü, 2016; Topcu ve Ersoy, 2019), benzer sonuçlara ulaşılmış ve öğrencilerin devamsızlık konusunda özensiz davrandıkları belirtilmiştir. Öğretmenler, katılımın zamanla azalmasına sebep olarak öğrencilerin kursa aile zoruyla gelmelerini göstermektedir. Öğretmenlere göre, bazı öğrenciler, kursları evden uzaklaşma aracı olarak görmekte ve kursları arkadaşlarıyla eğlenceli vakit geçirecekleri bir yer olarak algılamaktadır. Canpolat ve Köçer (2017) de yaptıkları çalışmada benzer sonuçlara ulaşarak öğrencilerin evden kaçmak için DYK'yı bir araç olarak gördüklerini belirtmiştir. Özetle öğretmenlerin kurslarda karşılaştığı sorunların büyük bir bölümünün, öğrencilerle ilgili olduğu söylenebilir. Öğretmenler, kursa katılım ve motivasyonu, kurs başarısının anahtarı olarak görmekte, devamsızlık ve motivasyonsuzluğu ise büyük bir sorun olarak algılamaktadır.

Kurslarda Türkçe öğretmenlerinin karşılaştığı önemli sorunlardan biri de müfredattır. Öğretmenlerin bu konuda ifade ettiği görüşlerin pek çoğu; kursun amacını, içeriğini ve sistemini sorgular niteliktedir. Kursun test çözme ve dil bilgisi ağırlıklı olması birçok öğretmen tarafından sorun olarak görülmektedir. Okul müfredatındaki Türkçe derslerinde, temel dil becerilerinin tamamına yönelik etkinlikler yapılırken kurslarda, daha çok LGS müfredatındaki konularda test çözmeye ve pratik yapmaya ağırlık verilmektedir. Bu tarz bir ders, bazı öğrenciler için çok eğlenceli olsa da bazıları için takip etmesi güç, yoğun ve sıkıcı bir ders olmaktadır. Bazı öğrencilerin; kendilerini sosyal, sportif ve sanatsal etkinliklerden uzaklaştırarak birer test makinesine dönüştüren (TED, 2010), bir kurs eğitiminden sıkılmaları son derece normaldir. Kurslara katılımın genel olduğu düşünüldüğünde, 
merkezî sınavlara hazırlanmak gibi birincil bir amacı olmayan öğrenciler için yoğun test odaklı bir dersin sıkıcı olacağı düşünülebilir. Bu çerçevede kursta, öğrencileri merkezî sınava hazırlayan bir Türkçe dersinin yanında onları rahatlatan, eğlendiren ve beceri olarak gelişimlerine katkı sağlayan bir Türkçe dersinin de olması gerektiği söylenebilir. Bu tarz bir derste öğrencilerin, güzel konuşma ve yazma, görsel okuma ve sunu gibi becerilerini geliştiren etkinlikler yapılabilir.

Türkçe öğretmenlerinin kurslarda karşılaştığı bir diğer problem de materyal yetersizliğidir. Öğretmenlerin, kursta kullanmak için hem kendilerinin kaynak sıkıntısı çektiğini hem de öğrencilerin evde çalışmaları için yeterli kaynağa sahip olmadıklarını belirttiği görülmüştür. Birçok öğretmen; maddi durumu iyi olan öğrencilerin bir şekilde kendilerine test kitabı alabildiğini, maddi durumu iyi olmayan öğrencilerin bu konuda sıkıntı yaşadığını ifade etmiştir. Bozbayındır ve Kara (2017), Er Türküresin (2018), Topcu ve Ersoy (2019) da yaptıkları çalışmalarda, öğretmenlerin en çok kaynak eksikliğinden şikâyetçi olduklarını belirtmiştir. Ek kaynak aldırmanın yasak olduğunu belirten öğretmenler, kaynak temini konusunda özellikle sorun yaşadıklarını dile getirmiştir.

Araştırmanın üçüncü alt problemi olan Türkçe öğretmenlerinin kursların daha verimli olması için bildirdiği görüşlerin, özellikle yönetim boyutuyla ilgili olduğu görülmüştür. Öğretmenler, yoğun olarak kurs günü ve saati ile ilgili önerilerde bulunmaktadır. Kursun hafta içi mi hafta sonu mu olması gerektiği ile ilgili bildirilen görüşlerin, birbiriyle çeliştiği de söylenebilir. Bazı öğretmenlere göre kurslar, okul çıkışı yorucu olacağı için hafta sonunun sadece bir gününde yapılmalı; bazılarına göre ise kurslar, çocukların eğlenme zamanı olarak gördükleri hafta sonlarında yapılmamalı, okul çıkışında yapılmalıdır. Destekleme ve yetiştirme kurslarının, hedeflenen faydayı sağlayabilmesi için ders saati ve gününün öğrenci ve öğretmenler için kabul edilebilir olması gerekir. Kursun ne zaman yapılması gerektiği ile ilgili öğrenci ve öğretmenlerden talep toplanarak belirlenmesinin daha sağlıkı olacağı söylenebilir.

Yönetim boyutu temasında yoğunlukla dile getirilen diğer öneriler, Türkçe ders saatinin artırılması ve müfredatın hafifletilmesiyle ilgilidir. Türkçe ders saatinin arttırımasının; öğrencilerin okuma ve anlama ile ilgili problemlerini çözeceği, öğretmenlerin diğer dil becerilerini geliştirmeye de fırsat sağlayacağı belirtilmektedir. Öğretmenlere göre müfredatın hafifletilmesi ve esnetilmesi, öğretmenlerin yetkisini arttıracak ve bölgesel şartların daha çok dikkate alınmasını sağlayacaktır.

Yönetim boyutunda belirtilen önerilerden, özellikle devamsızlık ve öğrenci seçimi ile ilgili olanlar dikkat çekmektedir. Bazı öğretmenler, kursa devamın sağlanması için devamsızlık yapan öğrencilere, yaptırım uygulanmasını önermektedir. Ünsal ve Korkmaz (2016) da yaptıkları çalışmada, öğrencilerin kursa devamlılığııın sağlanması konusunda, benzer önerilere rastlamıştır. Bazı çalışmalarda, kurslardaki devamsızlık sorunun çözümü için öğrencilerden düşük de olsa bir ücret talep edilmesi önerisi görülmektedir (Bozbayındır ve Kara, 2017; Canlı, 2019). Bu tarz bir uygulamanın, öğrenciler üzerinde aile baskısının artmasına neden olacağı söylenebilir. Bazı öğretmenler, kurslara ortalama şartı getirilip sadece öğrenmeye istekli olan öğrencilerin kursa alınmasını önermiştir. Öğretmenler, kursların bu şekilde daha etkili olacağını vurgulamaktadır. Bu tarz bir öneriye benzer çalışmalarda da rastlanmakta ve öğrencilerin kursa seçiminde, belirli ölçütlerin olması gerektiği ifade edilmektedir (Ünsal ve Korkmaz, 2016). Bu tarz bir uygulamanın, kursların temel hedefi olan eğitimde fırsat eşitliğini sağlama açısından sorunlara neden olacağı söylenebilir.

Öğretmen boyutunu ilgilendiren önerilerde, öğretmenlerin kursta eğlenceli, ilgi çekici etkinliklere yer vermesi gerektiği çokça vurgulanmaktadır. Bütün derslerin test ve sınav odaklı işlenmesi, öğrenciler tarafından sıkıcı bulunmaktadır. Öğretmenler, öğrencilerin kurslardan keyif alması için yoğun ders aktarımının azaltılmasını ve kurslarda sosyal etkinliklere yer verilmesi gerektiğini belirtmiştir. Bu tarz uygulamaların; öğrencilerin kurslara ilgisini arttıracağı, devamsızlık ve motivasyonsuzluk gibi sorunları azaltacağı düşünülmektedir. Bu boyutla ilgi bir diğer öneri ise öğretmenlerin kurslardaki derslerde, temel dil becerilerinin tamamına ağıllık vermesi gerektiğidir. Kurslarda dil bilgisi ağırlıklı bir ders işlendiği için temel dil becerileri geri planda kalmaktadır. Türkçe öğretiminin birincil amacı, öğrencilerin anlama ve anlatma becerilerini geliştirmek olduğu için bu becerilere kurslarda da ağırlık verilmesi gerekir. Kurslardaki Türkçe ders saatinin arttırılmasının, öğretmenlerin temel dil becerilerine ve sosyal etkinliklere yer vermesine katkı sağlayacağı düşünülmektedir. 
Türkçe öğretmenlerinin büyük bir kısmı kursların daha verimli ve etkili olması için materyal boyutunu ilgilendiren önerilerde bulunmuştur. MEB'in tüm kurslara, ücretsiz kaynak dağıtmasının gerekli olduğu görüşü, sıkça vurgulanmaktadır. Canlı (2019), Bozbayındır ve Kara (2017), Topcu ve Ersoy (2019), Ünsal ve Korkmaz (2016) da benzer sonuçlara ulaşarak, kaynak eksikliğinin giderilmesi gerektiğini belirtmektedir. Bu çalışmada öğretmenlerin kaynak probleminin çözümüyle ilgili belirttiği bir diğer öneri de akıllı tahtada kullanılabilecek etkinlik ve aktivitelerin arttırılması ve EBA'nın geliştirilmesi olmuştur. Teknolojinin bu kadar geliştiği bir dönemde eğitimde teknolojik materyallerin kullanılmasının kaçınıımaz olduğu vurgulanmaktadır. EBA son zamanlarda hızla bir gelişim sağladığı için kurslarda dijital kaynaklar göz ardı edilmemeli ve bu tür kaynaklar daha da geliştirilerek öğretmen ve öğrencilerin hizmetine sunulmalıdır.

Araştırmanın sonucunda elde edilen verilerin, destekleme ve yetiştirme kurslarının avantajlarının ve dezavantajlarının görülmesine ve bu kursların daha verimli olmasına katkı sağladığı söylenebilir. Bu çalışmanın bulgularından hareketle merkezî sınavlara hazırlanmak için verilen destekleme ve yetiştirme kurslarının yanında beceri geliştirici, hobi amaçlı kurslara da yer verilmesi gerektiği söylenebilir. Birçok öğrencinin merkezî sınavlara hazırlanmak gibi birincil bir amacı bulunmamaktadır. Bu öğrencilere yönelik Türkçe öğretmenleri tarafından tiyatro, güzel konuşma, yazarlık vb. alanlarda, keyifle katılacakları atölye çalışmaları formatında kurslar verilebilir. Merkezî sınavlara hazırlanma amacıyla açılan kurslarda da, verimin artması için MEB'in kaynak takviyesi yapması, öğrencilerin sosyal ihtiyaçlarına cevap verecek etkinliklerin düzenlenmesi ve Türkçe ders saatinin arttırılması gerektiği söylenebilir. DYK'lar gönüllülük esasına dayalı olduğundan, öğrenci katılımının artması için kursların ilgi çekici hale getirilmesi bir zorunluluktur.

\section{Araştırma ve Yayın Etiği}

Bu çalışmada "Yükseköğretim Kurumları Bilimsel Araştırma ve Yayın Etiği Yönergesi" kapsamında uyulması belirtilen tüm kurallara uyulmuştur. Yönergenin ikinci bölümü olan "Bilimsel Araştırma ve Yayın Etiğine Aykırı Eylemler" başlığı altında belirtilen eylemlerden hiçbiri gerçekleştirilmemiş̧ir.

\section{Etik Kurul izni}

Kurul adı = T.C. Gaziantep Üniversitesi, Sosyal ve Beşeri Bilimler Etik Kurulu Komisyonu Karar tarihi $=9$ Eylül 2020

Belge sayı numarası $=91611957 / 100 / 57047$

\section{Yazarların Katkı Oranı}

Makalenin hazırlanmasında, her iki yazar da eşit düzeyde (1. yazar \%50, 2. yazar \%50) katkı sunmuştur.

\section{Çıkar Çatışması}

Bu araştırmada, çıkar çatışması teşkil edebilecek herhangi bir durum ya da ilişki yoktur.

\section{Kaynaklar}

Akkaya, A. (2017). Destekleme ve yetiştirme kurslarının öğrenci görüşlerine göre değerlendirilmesi (Yayımlanmamış yüksek lisans tezi). Ahi Evran Üniversitesi Sosyal Bilimler Enstitüsü, Kırşehir.

Aküzüm, C. ve Saraçoğlu, M. (2018). Ortaokul öğretmenlerinin destekleme ve yetiştirme kurslarına yönelik tutumlarının incelenmesi. Turkish Journal of Educational Studies, 5(2), 97-121.

Atılgan, H. (2018). Türkiye'de kademeler arası geçiş: Dünü-bugünü ve bir model önerisi. Ege Eğitim Dergisi, 19(1), 1-18. doi: 10.12984/egeefd.363268

Bozbayındır, F. ve Kara, M. (2017). Destekleme ve yetiştirme kurslarinda (dyk) karşılaşılan sorunlar ve öğretmen görüşleri temelinde çözüm önerileri. Sakarya University Journal of Education, 7(2), 336-349. 
Bray, M., \& Lykins, C. (2012). Shadow education: Private supplementary tutoring and its implications for policy makers in Asia. Mandaluyong City: Asian Development Bank and Hong Kong, Comparative Education Research Centre.

Canlı, S. (2019). Okul yöneticilerinin ve öğretmenlerin destekleme ve yetiştirme kurslarına yönelik görüşleri. Cumhuriyet International Journal of Education, 8(2), 479-501. http://dx.doi.org/10.30703/cije.496769

Canpolat, U., \& Köçer, M. (2017). Destekleme ve yetiştirme kurslarının TEOG bağlamında sosyal bilgiler öğretmenlerinin görüşlerine dayalı olarak incelenmesi. Anadolu Journal of Educational Sciences International, 7(1), 123-154.

Creswell, J. W. (2013). Nitel araştırma yöntemleri; beş yaklaşıma göre nitel araştırma ve araştırma deseni (M. Bütün ve S. B. Demir, Çev.). Ankara: Siyasal Kitapevi.

Dönmez, İ., Gürbüz, S. ve Tekçe, M. (2018). Destekleme ve yetiştirme kurslarının yönetici, öğretmen ve öğrenci görüşlerine dayanarak fırsat eşitliği açısından değerlendirilmesi. Eskişehir Osmangazi Üniversitesi Türk Dünyası Uygulama ve Araştırma Merkezî Eğitim Dergisi 3(2), 45-58.

Er Türküresin, H. (2018). Destekleme ve yetiştirme kurslarının öğretmen ve öğrenci görüşlerine göre incelenmesi. Kütahya Illi Örneği. Adnan Menderes Üniversitesi Eğitim Fakültesi Eğitim Bilimleri Dergisi, 9(2), 73-85.

Göksu, i. ve Gülcü, A. (2016). Ortaokul ve liselerde uygulanan destekleme kurslarıyla ilgili öğretmen görüşleri. Bayburt Eğitim Fakültesi Dergisi, 11(1), 153-171.

Güven, i. (2010). Türk eğitim tarihi. Ankara: Naturel.

Kanat, Ö. (2005). Türk-Alman genel eğitim sistemlerinin karsılaştııılması (Yayımlanmamış yüksek lisans tezi). Marmara Üniversitesi, İstanbul.

Keskin, A. ve Kazak, E. (2020). Hafta içi uygulanan destekleme ve yetiştirme kurslarına ilişkin öğrenci görüşleri: Fenomenolojik bir çalışma. Cumhuriyet Uluslararası Eğitim Dergisi, 9(3), 820-844.

Kösterilioğlu, i. (2015). Eğitimde dershaneler mi? Dershanede eğitim mi?. International Online Journal of Educational Sciences, 7(1), 203-218.

Merriam, S. B. (2013). Nitel araştırma desen ve uygulama için bir rehber (S. Turan, Çev.). Ankara: Nobel Yayıncilık.

Millî Eğitim Bakanlığı. (2016). Destekleme ve yetiştirme kursları e-kılavuzu. Erişim adresi: http://meb.gov.tr/sinavlar/dokumanlar/2017/2017_2018_DYK.pdf

Milî̂ Eğitim Bakanlı̆ı̆. (2019b). Destekleme ve yetiştirme kursları yeniden düzenleme. Erişim adresi: http://www.meb.gov.tr

Millî Eğitim Bakanlığı. (2014). Örgün ve yaygın eğitimi destekleme ve yetiştirme kursları yönergesi. Erişim adresi: http://mevzuat.meb.gov.tr/dosyalar/1714.pdf

Millî Eğitim Bakanlığı. (2017-2018). Örgün ve yaygın eğitimi destekleme ve yetiştirme kursları tanıtım kitapçı̆̆ı. Erişim adresi: http://odsgm.meb.gov.tr/mebiysdosyalar/201712/18122830_ dykkit.pdf

Millî Eğitim Bakanlığı. (2019a). PISA 2018 Türkiye ön raporu. Erişim adresi: http:// www.meb.gov.tr/mebiysdosyalar/2019_12/03105347_PISA_2018Turkiye_On_Raporu.pdf

Millî Eğitim Bakanlığı. (2020). Destekleme ve yetiştirme kursları yönergesi. Erişim adresi: http://ogm.meb.gov.tr/mebiys_dosyalar/2020_10/26191853_DesteklemeveYetiYtirmeKursla rYYonergesi.pdf

Morgil, i.,Yılmaz, A. ve Geban, Ö. (2001). Özel dershanelerin üniversiteye girişte öğrenci başarısına etkileri. Hacettepe Üniversitesi Eğitim Fakültesi Dergisi, 21, 89-96.

Nartgün, Ş. S. ve Dilekçi, Ü. (2016). Eğitimi destekleme ve yetiştirme kurslarına ilişkin öğrenci ve öğretmen görüşleri. Kuram ve Uygulamada Eğitim Yönetimi, 22(4), 537-564. doi: 10.14527/kuey.2016.021

Özoğlu, M. (2011). Özel dershaneler: gölge eğitim sistemiyle yüzleşmek. Seta Analiz.

Patton, M. Q. (2014). Nitel araştırma ve değerlendirme yöntemleri (M. Bütün ve S. B. Demir, Çev.). Ankara: Pegem Akademi.

Sarıca, R. (2019). Destekleme ve yetiştirme kurslarına (DYK) yönelik öğretmen görüşleri. Millî Eğitim, 48(221), 91-122. 
Tan, C. (2017). Private supplementary tutoring and parentocracy in singapore. Interchange, 48, 315329. doi: 10.1007/s10780-017-9303-4

Tansel, A. (2013). Türkiye'de özel dershaneler: Yeni gelişmeler ve dershanelerin geleceği. Discussion Paper, No. 2013/17, Turkish Economic Association, Ankara.

TED. (2006). Hayat = 195 dk. mı ? Ankara: Türk Eğitim Derneği.

TED. (2010). Ortaöğretime ve yükseköğretime geçiş sistemi. Ankara: Türk Eğitim Derneği.

Tezcan, M. (1997). Eğitim sosyolojisi. Ankara: Zirve Ofset.

Topcu, i. ve Ersoy, M. (2019). MEB destekleme ve yetiştirme kurslarının öğretmen görüşleri kapsamında değerlendirilmesi. E-Uluslararası Eğitim Araştırmaları Dergisi, 10(3), 61-75. doi: 10.19160/ijer.645227

Türkiye Büyük Millet Meclisi. (2020). Türkiye Cumhuriyeti Anayasanın 42. Maddesi. Erişim adresi: https://www.tbmm.gov.tr/develop/owa/tc_anayasasi.maddeler?p3=42

Uğurlu, F. (2017). Destekleme ve yetiştirme kurslarında görevli öğretmenlerin kurslara yönelik öz algı düzeylerinin incelenmesi (Ordu ili örneği) (Yayımlanmamış yüksek lisans tezi). Amasya Üniversitesi, Amasya.

Ünsal, S., \& Korkmaz, F. (2016). Destekleme ve yetiştirme kurslarının işlevlerine ilişkin öğretmen görüşlerinin incelenmesi. KSÜ Sosyal Bilimler Dergisi, 13(12), 87-118.

Yıldııı, A. ve Şimşek, H. (2013). Sosyal bilimlerde nitel araştırma yöntemleri. Ankara: Seçkin Yayıncılık. Yirci, R. ve Açıkgöz, M. Y. (2018). Destekleme ve yetiştirme kurslarına yönelik yönetici, öğretmen ve öğrenci görüşlerinin incelenmesi. V. Uluslararası eğitim bilimleri sempozyumu tam metin kitabı (s. 169-186). İstanbul: Asos Yayınevi.

\section{Introduction}

\section{Extended Abstract}

Central exams, which are taken to advance to a more prestigious higher-level education institution in the education system, direct students to tutoring institutions. Students are expected to get high scores in central exams in order to be placed in prestigious high schools and universities. The education provided in schools is seen by many students and parents to be inadequate to achieve good results in central exams (TED, 2010). Students turn to private education institutions in order to improve their skills such as multiple-choice test techniques, time management, exam strategies, etc. The demand for private education institutions in our country is generally explained by the existence of central exams. However, this situation is not unique to our country. In many countries where there are competitive examination systems for the transition between educational levels, private tutoring and teaching are quite common (Tansel \& Bircan, 2006, as cited in Özoğlu, 2011, p. 18).

The international trend in education is towards complementary education, called shadow education (Tan, 2017). In many countries, students can take private lessons as supplementary education in addition to formal education. Complementary education activities can take place in the education system of a country as follows: (1) One-on-one private tutoring, (2) private tutoring institutions that are organized in a similar way to schools, (3) school teachers lecturing for a fee outside the school hours in school (Tansel, 2013, p. 11). While in countries such as Singapore, Hong Kong, South Korea, and Taiwan, private tutoring by a school teacher is more common (Bray \& Lykins, 2012), private tutoring institutions are common in our country. The most emphasized problem regarding private education institutions worldwide is the equality of opportunity. It is stated that students from lowincome families cannot benefit from the practices in the first and second groups (see above Tansel, 2013, p. 11) because of their high costs. When evaluated in terms of equal opportunity, it can be said that tutoring institutions cause major issues (Göksu \& Gülcü, 2016). The commercialization of educational services, financial difficulties of families from poor economic backgrounds, negative effects on the educational activities carried out in schools, and inducement to rote learning can be listed among the prominent issues. The Ministry of National Education (MEB) launched the abovementioned third group (see above Tansel, 2013, p. 11) private education institution service in 20142015 to ensure equal opportunities in education. As of this academic year, courses have been offered 
in all middle and high schools as part of supportive education (MEB, 2014). The aim of these courses that are offered for free is to increase the equality of opportunity in education.

There are many academic studies on the efficiency and shortcomings of supporting and training courses. These studies are extremely important as they offer an impartial and critical perspective. In the studies on this subject, the efficiency of the supporting and training courses, and the attitude towards these courses have been analysed in terms of students', teachers', and administrators' opinions. The study's key point is that there is no study explicitly for Turkish language teaching and Turkish teachers among the research on supporting and training courses. The fact that there has not been enough research on the support and training courses, which is a six-year practice, on the basis of branches, and that there is no study on the Turkish language, Turkish being the mother tongue, and Turkish teachers who take active roles in the courses, are the factors that increase the importance of the study. The aim of this study is to examine the efficiency of Turkish lessons in supporting and training courses and determine the problems experienced in these lessons according to teachers' opinions. The following questions were asked in this study:

1. How do Turkish teachers evaluate the supporting and training courses?

2. Should the Ministry of Education continue this practice?

3. What are the problems do Turkish teachers encounter regarding Turkish classes in supporting and training courses?

4. What can be done to make the courses more effective and efficient?

\section{Method}

The study was carried out using the method of phenomenology, which is one of the qualitative methods of research. The participants of the study were determined using criteria sampling and maximum diversity sampling techniques, which are among purposive sampling methods. The criteria used to determine the participants of the study were defined as having worked as a Turkish teacher for at least one year in supporting and training courses, and voluntarily participating in research. The working group of the research consisted of 26 Turkish teachers working in middle schools in different cities. A structured interview form developed by the researchers was used in the collection of data. The interview form was sent to the participating teachers via Google Form and data were collected in this way. Moreover, in the study, a 40-minute meeting was held on Zoom with 12 participants, who accepted the online meeting request on the interview form. The data of the research were analysed by the content analysis method. In the in-depth examination, more than one person read the participant forms, and common codes were determined. Later, the themes were determined by creating categories using the codes obtained. Various measures have been taken to ensure the validity and reliability of the study, and its compliance with ethical principles.

\section{Result and Discussion}

According to the findings obtained in the study, the majority of Turkish teachers ( $f=23$ ) support the implementation of supporting and training courses and think that the Ministry of Education should continue this practice. The teachers expressed that especially the fact that the courses provide equal opportunity in education was the reason for these beliefs. According to most teachers $(f=14)$, the courses enabled students from poor economic backgrounds, in the exam preparation process, to improve their test techniques and be more successful. According to the teachers, the courses reduced the difference in success between students who have insufficient financial means and those who can afford private lessons and private education institutions. The most important goal of supporting and training courses is to remove the economic barriers to education. The majority of Turkish teachers $(f=23)$ emphasized that the courses fulfil this goal, and it would be beneficial to continue the courses. Similar results can be found in other studies in the literature (Aküzüm \& Saraçoğlu, 2018; Canlı, 2019; Er Türküresin, 2018; Uğurlu, 2017).

Although the courses provide equal opportunity and various advantages, there are also some features that are viewed as negative by teachers. Teachers state that there are some disadvantages of the courses for them and their students, reducing the expected efficiency of the course. It is stated 
that the unsuitability of the day and time of the course leads to demotivation, fatigue, and absenteeism in students. One of the important problems faced by Turkish teachers in the courses is related to the curriculum. Most of the opinions expressed by teachers on this issue question the purpose, content, and system of the course. Many teachers see the fact that the course is based on multiple-choice test solving and grammar as a problem.

Based on the findings of this study, it can be said that in addition to supporting and training courses for central exam preparation, there should also be courses centred on skill development and hobbies. Many students do not have a primary goal of preparing for central exams. Turkish teachers can offer these students courses, such as workshops, drama courses, speaking courses, writing courses, and so on. It can be concluded that the Ministry of National Education should supplement resources and organize activities in a way that meets the social needs of students in order to improve efficiency in the courses produced for central exam preparation. Since participating in the supporting and training courses is voluntary, courses should be made interesting to encourage students to participate. 